\title{
HUBUNGAN RATIO NEURTOFIL DAN LIMFOSIT PADA PENDERITA PENYAKIT INFEKSI VIRUS DENGUE
}

\author{
${ }^{1}$ Karla C. Nusa \\ ${ }^{2}$ Max F.J. Mantik \\ ${ }^{2}$ Novie Rampengan
}

\author{
${ }^{1}$ Kandidat Skripsi Fakultas Kedokteran Universitas Sam Ratulangi Manado \\ ${ }^{2}$ Bagian Ilmu Kesehatan Anak Fakultas Kedokteran Universitas Sam Ratulangi Manado \\ Email : knusa11_166@yahoo.com
}

\begin{abstract}
Dengue virus infection exhibit different symptoms. WHO estimated that every year, 50 million humans are infected with dengue virus and $90 \%$ of the inward patients are children. Based on WHO (2011) laboratory criteria, there are several blood test result such as leukocytes, thrombocytes, hematocrits that play important role in determining clinical course of dengue infection. Leukocytes consist of 5 different types, which include neutrophil, eosinophil, basophil, monocytes and lymphocytes. Based on recent research, neutrophillymphocytes count ratio (NLCR) can be used as a marker to differentiate bacterial infection from viral infection. The purpose of this study is to know the relationship between neutrophil and lymphocyte ratio on dengue virus patients in Prof DR. R. D. Kandou Hospital in Manado. It is an analytical retrospective research in which the data collected from medical record of dengue virus patients who were admitted during the period of March 2013-Mei 2014. The data is then processed using Spearman's correlation test. The result $\mathrm{p}=0,630(\mathrm{p}>0,05)$. Conclusion: There is no significant relationship between neutrophil and lymphocytes ratio on dengue virus patients.
\end{abstract}

Keywords: dengue virus infection, neutrophil to lymphocyte ratio, children.

\begin{abstract}
Abstrak: Infeksi virus dengue menimbulkan gejala yang bervariasi. WHO memperkirakan setiap tahun sekitar 50 juta manusia terinfeksi virus dengue yang hampir $90 \%$ dari pasien rawat inap adalah anak-anak. Berdasarkan kriteria laboratoris WHO (2011), terdapat beberapa hasil pemeriksaan darah seperti leukosit, trombosit, hematokrit, yang berperan penting dalam perjalanan klinis infeksi dengue. Tipe leukosit terdiri dari lima jenis, antara lain neutrofil, eosinofil, basofil, monosit dan limfosit. Didukung dengan hasil penelitian terbaru, sebagai penanda untuk membedakan antara infeksi bakteri dan virus maka digunakan ratio hitung neutrofil dan limfosit (NLCR). Tujuan penelitian ini untuk mengetahui hubungan antara ratio neutrofil dan limfosit pada penderita infeksi virus dengue di RSUP Prof. DR. R.D. Kandou Manado. Penelitian ini bersifat analitik retrospektif, diambil dalam bentuk data rekam medik periode Maret 2013-Mei 2014. Data diolah dengan menggunakan uji korelasi Spearman. Hasil analisa data didapatkan nilai $P=0,630(\mathrm{p}>0,05)$. Kesimpulan : Tidak terdapat hubungan yang signifikan antara ratio neutrofil dan limfosit pada penderita infeksi virus dengue.
\end{abstract}

Kata kunci: infeksi virus dengue, ratio neutrofil dan limfosit, anak-anak.

Infeksi virus dengue menimbulkan gejala yang bervariasi, mulai dari tanpa gejala, gejala ringan sampai berat. Gejala yang berat ini dikaitkan dengan penyakit demam dengue dan demam berdarah dengue (DBD). ${ }^{1}$ WHO (1997) membagi DBD 
dalam empat derajat. Derajat I dan II disebut DBD tanpa syok, derajat III dan IV disebut DBD dengan syok atau SSD. ${ }^{2}$

Virus dengue termasuk dalam kelompok B Arthropod Virus (Arbovirosis), yang sekarang dikenal sebaga genus flavivirus, family Flaviviridae. ${ }^{3}$ Salah satu faktor yang mempengaruhi transmisi dan penularan virus dengue adalah melalui gigitan nyamuk Aedes Aegypti dan Aedes Albopictus. ${ }^{1}$ Kelompok arbovirus yang menginfeksi manusia tersebut semuanya diduga bersifat zoonotic; manusia hanya merupakan pejamu secara kebetulan dan tidak memiliki peran penting dalam siklus transmisi atau pemeliharaan virus. ${ }^{4}$

Kenyataannya sekarang, virus dengue menempati urutan ke delapan sebagai penyebab kesakitan di negara-negara kawasan Asia Tenggara dan Pasifik Barat. ${ }^{5}$ Di Indonesia, infeksi dengue menyebabkan epidemi berulang. Pada anak-anak yang terbanyak terkena infeksi dengue adalah kelompok umur 4-10 tahun. ${ }^{6}$ Data yang ada sampai akhir tahun 2005, DBD telah ditemukan di seluruh provinsi Indonesia. Hal ini menerangkan bahwa hampir semua populasi manusia berpotensi terinfeksi virus dengue dan bersifat asimtomatik.

Kunci keberhasilan penanganan pasien dengan infeksi dengue, salah satunya adalah melakukan pemeriksaan darah lengkap. Kriteria WHO (2011) terdapat beberapa hasil pemeriksaan darah seperti leukosit, trombosit, dan hematokrit yang berperan penting dalam perjalanan klinis infeksi dengue. ${ }^{1}$ Tipe leukosit terdiri dari 5 jenis, antara lain : neutrofil, eosinofil, basofil, monosit dan limfosit.

Didukung dengan hasil penelitian terbaru yang dilakukan sebagai penanda untuk membedakan antara infeksi bakteri dan virus maka digunakan ratio hitung neutrofil dan limfosit (NLCR). Cut off value NLCR 6,2 menunjukkan tingkat sensitivitasnya 0,91 dan tingkat spesifitas 0,96. Hasil ini menunjukkan potensi NLCR sebagai tes diagnostik. ${ }^{7}$

Dari penjelasan diatas, maka penulis berkeinginan melakukan analisis hubungan ratio neutrofil dan limfosit pada pasien anak yang terinfeksi virus dengue di RSUP. Prof. Dr. R. D. Kandou bagian Ilmu Kesehatan Anak Manado.

\section{TUJUAN PENELITIAN}

Untuk mengetahui adakah hubungan ratio neutrofil limfosit pada anak yang mengalami infeksi virus dengue dan mengetahui derajat klinis yang paling banyak diderita, serta memprediksi terjadinya perembesan plasma darah pada anak yang terifeksi virus dengue yang dirawat di Bagian Ilmu Kesehatan Anak RSUP Prof. Dr. R. D. Kandou.

\section{PATOGENESIS}

Patogenesis infeksi dengue masih merupakan masalah yang kontroversial. Ada dua teori hipotesis yang digunakan untuk menjelaskan perubahan patogenesis pada infeksi dengue yaitu hipotesis infeksi sekunder (teori secondary heterologous infection) dan hipotesis antibody dependent enchancement (ADE). ${ }^{8}$

Teori secondary heterologous infection secara singkat menyatakan bahwa seseorang yang pernah mendapat infeksi primer virus dengue, akan mempunyai antibodi yang dapat menetralisir yang sama (homologous). Tapi jika orang tersebut mengalami infeksi yang kedua kalinya dengan serotipe virus dengue yang heterolog maka orang tersebut mempunyai resiko yang lebih besar untuk menderita DBD yang lebih berat. ${ }^{8}$

Pada teori kedua (ADE), menyebutkan tiga hal yaitu antibodies enhance infection, $\mathrm{T}$-cells enhance infection serta limfosit $\mathrm{T}$ dan monosit akan melepaskan sitokin yang berkontribusi terhadap terjadinya DBD dan SSD. Singkatnya secara umum ADE dijelaskan sebagai berikut : bahwa jika terdapat antibodi spesifik terhadap jenis virus tertentu, maka antibodi tersebut dapat mencegah penyakit, tetapi sebaliknya apabila antibodi yang terdapat dalam tubuh merupakan antibodi yang tidak dapat menetralisir virus, justru dapat menimbulkan penyakit yang berat. ${ }^{8}$ 


\section{LEUKOSIT}

Leukosit terdiri dari dua golongan utama, yaitu agranular dan granular. Terdapat dua jenis leukosit agranular yaitu limfosit yang terdiri dari sel-sel kecil dengan sitoplasma sedikit, dan monosit yang terdiri dari sel-sel yang agak besar dan mengandung sitoplasma lebih banyak. Terdapat tiga jenis leukosit granular yaitu eosinofil, neutrofil, dan basofil. .

\section{NEUTROFIL}

Neutrofil adalah leukosit granular matur polimorfonuklear, memiliki daya lekat dengan kompleks imun, dan kemampuan fagositosis. Neutrofil memiliki jumlah terbanyak di dalam darah yaitu 4.000$10.000 \mathrm{~mm}^{3}$. Adapun morfologi terdiri dari

a. Neutrofil batang :

- Ukuran rata-rata $12 \mu \mathrm{m}$

- Sitoplasma tidak berwarna penuh dengan granula-granula yang sangat kecil dan berwarna coklat kemerahan sampai merah muda

- Kira-kira 2/3nya merupakan granula spesifik sedangkan yang 1/3nya merupakan granula azurofilik (merah biru-ungu)

- Nukleus lebih tebal, berbentuk huruf U dengan kromatin kasar dan rongga parakromatin yang agak jelas batasnya

- Jumlahnya 0-6\% dari leukosit total $\left(0-0,7 \times 10^{9} / \mathrm{L}\right)$. . $^{10}$

b. Neutrofil tangkai/segmen :

- Ukuran rata-rata $12 \mu \mathrm{m}$

- Sitoplasma dan granula sama dengan neutrofil batang

- Nukleus gelap, berbentuk seperti huruf E, Z, atau S yang terpisah menjadi segmen-segmen/lobuslobus yang dihubungkan oleh filamen-filamen yang halus

- Banyaknya lobus pada neutrofil normal berkisar antara 2-5 lobus, dengan rata-rata tiga lobus

- Jumlahnya 40-54\% dari leukosit total $\left(1,3-7,0 \times 10^{9} / \mathrm{L}\right){ }^{10}$

\section{LIMFOSIT}

Limfosit berperan sebagai sistem imun yang spesifik. Imunitas spesifik hanya ditujukan terhadap antigen tertentu yaitu antigen yang merupakan ligannya. Di samping itu, respons imun spesifik juga menimbulkan memori imunologis yang akan cepat bereaksi bila host terpajan lagi dengan antigen yang sama dikemudian hari. Pada imunitas didapat, akan terbentuk antibodi dan limfosit efektor yang spesifik terhadap antigen yang merangsangnya sehingga terjadi eliminasi antigen. Sel yang berperan dalam imunitas didapat ini adalah sel yang mempresentasikan antigen $(A P C=$ antigen presenting cell = makrofag) sel limfosit $\mathrm{T}$ dan sel limfosit B. Sel limfosit T dan limfosit $\mathrm{B}$ masing-masing berperan pada imunitas seluler dan imunitas humoral. $^{11}$

\section{HUBUNGAN RATIO NEUTROFIL DAN LIMFOSIT DENGAN INFEKSI VIRUS DENGUE}

Salah satu respons fisiologis pada sistem imunitas terhadap inflamasi sistemik adalah peningkatan jumlah neutrofil serta penurunan jumlah limfosit. ${ }^{12}$

Zahorec et al, mendokumentasikan bahwa nilai NLCR merupakan parameter yang dapat diukur secara mudah untuk mengindikasikan tingkat keparahan inflamasi sistemik dan sepsis pada 90 pasien onkologi. ${ }^{7}$ NLCR juga merupakan parameter yang berguna dalam mendeteksi bakteremia dalam penanganan emergensi. ${ }^{7}$

Namun terdapat kekurangan informasi mengenai potensi kegunaan NLCR untuk membedakan infeksi bakteri yang parah dengan infeksi virus. Dijelaskan bahwa NLCR merupakan marker diagnostik yang murah dan mudah untuk dinilai karena tidak memerlukan alat yang khusus dalam pengukurannya. Sama dengan PCT, perubahan pada hitung sel darah putih sangat cepat, menunjukan peran neutrofil pada respon inflamasi tingkat awal. ${ }^{7}$

Hal lain yang dapat dilihat pada infeksi virus dengue yaitu ditemukan hasil hitung darah putih dapat normal atau ditemukan 
neutrofil yang predominan pada fase awal demam. Setelah itu, terjadi penurunan total dari jumlah sel darah putih dan neutrofil, mencapai level terendah pada akhir fase dari demam. Perubahan pada jumlah sel darah putih $\left(\leq 5000 \mathrm{sel} / \mathrm{mm}^{3}\right)$ dan ratio neutrofil terhadap limfosit (neutrofil<limfosit) berguna untuk memprediksi periode kritis dari kebocoran plasma. Perubahan tadi muncul sebelum terjadinya trombositopenia atau peningkatan hematokrit. Limfositosis relatif dengan peningkatan limfositosis atipikal biasanya ditemukan pada fase akhir demam atau pada masa perbaikan. ${ }^{1}$

\section{METODE PENELITIAN}

Penelitian yang dilakukan bersifat analitik retrospektif, data diambil dari data rekam medik pasien anak yang dirawat di Bagian Ilmu Kesehatan Anak RSUP Prof.Dr.R.D. Kandou Manado dari bulan November-Desember 2014. Sampel penelitian adalah semua anak yang didiagnosa menderita infeksi virus dengue periode Maret 2013-Mei 2014. Variabel bebas adalah derajat klinis infeksi dengue, dan variabel terikat adalah ratio jumlah neutrofil dan limfosit. Analisis data menggunakan uji korelasi Spearman dengan program SPSS versi 20.

\section{Definisi Operasional}

1. Neutrofil : Memiliki dua morfologi yaitu neutrofil batang dan segmen, menunjukkan hasil yang dapat normal atau dengan peningkatan, selanjutnya diikuti penurunan dan mencapai titik terendah pada akhir fase demam infeksi dengue. ${ }^{13}$

2. Limfosit adalah menunjukkan peningkatan pada fase akhir demam infeksi dengue. ${ }^{13}$

3. Ratio neutrofil dan limfosit : perubahan jumlah neutrofil dan limfosit yang menunjukkan neutrofil < limfosit. ${ }^{13}$

4. Demam dengue : Penyakit akut, dapat sembuh spontan, dan biasanya berlangsung 5 hingga 7 hari, ditandai dengan demam, lesu, nyeri otot yang berat, nyeri kepala, ruam, limfadenopati, dan leukopenia. ${ }^{14}$

5. Demam berdarah dengue tanpa syok : Proses kelanjutan yang serius dari dengue klasik, ditandai dengan manifestasi perdarahan seperti trombositopenia dan hemokonsentrasi. 14

6. Demam berdarah dengue dengan syok : Disertai oleh kegagalan sirkulasi dan agitasi, syok hebat disertai tekanan darah dan denyut nadi yang tidak terdeteksi. ${ }^{14}$

\section{HASIL PENELITIAN}

Total jumlah sampel yang didapat sebanyak 80 sampel pasien anak. Terdiri dari 45 (56,3\%) anak laki-laki dan 35 (43,8\%), berumur 1-13 tahun. Berdasarkan kelompok umur, anak umur 4 tahun (12,5\%) paling banyak menderita infeksi dengue diikuti anak usia 1 dan 11 tahun (11,3\%), sedangkan anak dengan usia 9 tahun (1,3\%) yang paling sedikit mengalami infeksi dengue. Kebanyakan anak-anak dirawat dengan diagnosis demam dengue sebanyak 59 anak (73,8\%), DBD tanpa syok 16 anak (20,0\%) dan DBD dengan syok 5 anak $(6,3 \%)$. 
Tabel 1. Karakteristik anak yang menderita infeksi virus dengue berdasarkan jenis kelamin dan umur

\section{Jumlah Penderita Infeksi Virus Dengue}

Variabel

(n) (\%)

Jenis Kelamin

Laki - laki $\quad 45 \quad 56,3$

Perempuan $\quad 35 \quad 43,8$

Umur anak $\quad 35 \quad 43,8$

$1-5 \quad 38 \quad 47,6$

$6-10 \quad 27 \quad 33,9$

$11-13 \quad 15 \quad 18,9$

Total $\quad 80 \quad 100$

Tabel 2. Distribusi sampel berdasarkan derajat infeksi dengue

Penderita Infeksi Virus $\quad \mathrm{N} \quad \%$

Dengue

\begin{tabular}{ccc}
\hline Demam dengue & 59 & 73,8 \\
DBD tanpa syok & 16 & 20,0 \\
DBD dengan syok & 5 & 6,3 \\
total & 80 & 100 \\
\hline
\end{tabular}

Tabel 3. Hasil analisis korelasi ratio neutrofil dan limfosit dengan infeksi virus dengue Ratio neutrofil limfosit dihitung secara manual, menggunakan rumus :

Ratio $=\frac{\text { batang }+ \text { segmen }}{\text { limfosit }}$

\begin{tabular}{lccccc}
\hline & \multicolumn{4}{c}{ Ratio } & \\
\cline { 2 - 4 } & Mean & SD & Minimum & Maksimum & \\
$\begin{array}{l}\text { Demam } \\
\text { Dengue }\end{array}$ & 0,9 & 1 & 0,00 & 7,6 & \\
$\begin{array}{l}\text { DBD tanpa } \\
\text { syok }\end{array}$ & 0,7 & 0,3 & 0,35 & 1,3 & $\mathrm{P}=0,630$ \\
$\begin{array}{l}\text { DBD dengan } \\
\text { syok }\end{array}$ & 0,9 & 0,6 & 0,42 & 2 &
\end{tabular}

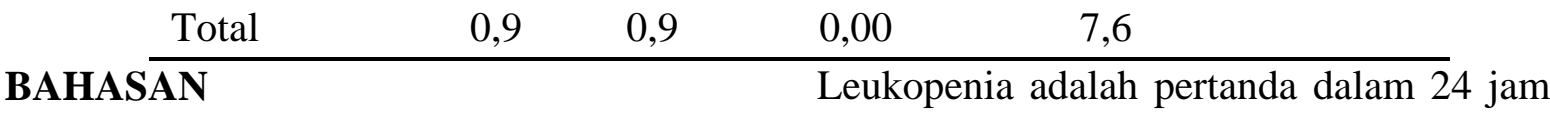

Penatalaksanaan kasus DBD rawat kemudian demam akan turun dan pasien inap di RS biasanya menggunakan nilai akan masuk dalam masa kritis.

hematokrit dan jumlah trombosit sebagai indikator perkembangan penyakit selain kondisi klinis pasien. Sedangkan jumlah leukosit seringkali diabaikan dalam penatalaksanaan kasus DBD. ${ }^{15}$ Telah dijelaskan sebelumnya yaitu pada infeksi virus umumnya akan disertai leukopenia.

Masa kritis pada DBD singkat, berkisar antara 48-72 jam yang biasanya terjadi pada hari ke 5-7 dengan masa penyembuhan yang cepat dan tanpa gejala sisa, seperti pada syok septik. Sepsis berhubungan dengan migrasi leukosit yang diaktivasi dari aliran darah ke jaringan 
inflamasi dan bersamaan dengan produksi leukosit di sum-sum tulang yang intensif dikeluarkan ke aliran darah sebagai sel leukosit immatur. Ketika leukosit melekat pada endotel, gangguan vaskuler mulai terjadi. Perlekatan ini terjadi karena teraktivasinya endotel, neutrofil, dan limfosit oleh sitokin dan kemokin yang dikeluarkan monosit/makrofag. ${ }^{15}$

Pada penelitian ini, diambil hasil pemeriksaan hitung jenis sel darah putih untuk neutrofil dan limfosit yang dilakukan pada hari ke 2, 3, 4, 5, 6, dan 7. Dengan menggunakan uji statistik analisis korelasi Spearman, tidak didapatkan hubungan yang signifikan antara ratio neutrofil dan limfosit dengan infeksi virus dengue, diperoleh nilai $p=0,630$. Ada beberapa hal yang mempengaruhi hasil perhitungan jumlah leukosit yaitu kualitas dan jenis alat yang digunakan dan keterampilan petugas laboratorium yang memeriksa. ${ }^{15}$

Dari sumber kepustakaan dikatakan pada saat demam, mulai terjadi pengurangan jumlah leukosit dan neutrofil disertai limfositosis relatif. Perubahan jumlah leukosit ini disebut sebagai ratio neutrofil limfosit (neutrofil<limfosit), yang berperan dalam memprediksi masa kritis perembesan plasma. ${ }^{13}$

Dari keseluruhan proses analisis yang dilakukan ini, terdapat keterbatasan peneliti dalam mengumpulkan data rekam medik yang kebanyakan tidak lengkap dan data pemeriksaan rekam medik terhadap neutrofil dan limfosit yang dilakukan pada hari yang berbeda, serta hasil pemeriksaan yang tidak semuanya menunjukkan adanya neutropenia dan limfositosis (ratio neutrofil limfosit). Keterbatasan lainnya, peneliti tidak melakukan penelitian lanjut terhadap faktor-faktor lain yang mempengaruhi pasien infeksi virus dengue.

\section{SIMPULAN}

Dari penelitian yang dilakukan, dapat disimpulkan bahwa:

1. Infeksi virus dengue paling banyak ditemukan pada anak laki-laki dan anak usia 4 tahun.

2. Derajat klinis infeksi dengue yang paling banyak diderita anak-anak adalah demam dengue.

3. Tidak ditemukan hubungan yang signifikan antara ratio neutrofil dan limfosit pada penyakit infeksi virus dengue.

\section{DAFTAR PUSTAKA}

1. WHO. Comprehensive Guidelines for prevention and control of dengue and dengue haemorragic fever. Revised and expanded edition. New Delhi: WHO, Regional Office for South-East Asia; 2011. p. 1-26.

2. Ari LR. Studi perbandingan pengobatan demam berdarah dengue derajat III dan IV. Sari Pediatri. 2007; 8(3): 42-7.

3. Achmadi UF, Sudjana P, Sukowati S, Wahyono TYM, Haryanto B, Mulyono S, et al. Demam berdarah dengue. Buletin Jendela Epidemiologi. Volume 2. Agustus 2010. p. 1-3.

4. Jawetz, Melnick, Adelberg. Penyakit virus yang ditularkan oleh artropoda dan rodentia. Dalam : Retna NE, Dian R, Sherli K, Fara I, Srie SPR, Peni Y, editors. Mikrobiologi kedokteran. Ed 23. Jakarta : EGC. 2007.p.524.

5. Sumarmo PS. Demam berdarah dengue. Edisi ke-2. Jakarta : FKUI; 1999.p. 1-12.

6. Septiani G, IDAI. Demam berdarah dengue, masalah dan cara penanggulangannya. 2009 April 25 [cited 2014 Sep 13]. Diunduh dari : https://ginaseptiani.wordpress.com/2009/04 /25/demam-berdarah-dengue-masalah-dancara-penanggulangannya/

7. Holub M, Beran O, Kasprikova N, Chalupa P. Neutrophil to lymphocyte count ratio as a biomarker of bacterial infections. Cent Eur J Med. 2011; 39: 411$17 .$.

8. Soegijanto S. Patogenesa dan perubahan patofisiologi infeksi virus dengue. 2013 Oct 31 [cited 2014 Sep 13]. Diunduh dari:https://www.scribd.com/doc/17240062 4/DBD-Patofisiologi

9. Sridianti F. Pengertian leukosit. 2014 Sep 7 [cited 2014 Sep 13]. Diunduh dari : http://www.sridianti.com/pengertianleukosit.html

10. Gandasoebrata R. Penuntun Laboratorium Klinik. Jakarta: Dian Rakyat,2001.p.32-3.

11. Purwono. Fisiologi imun dan mekanisme pertahanan. 2009 July 5 [cited 2014 Sep 
Jurnal e-Clinic (eCl), Volume 3, Nomor 1, Januari-April 2015

25]. Diunduh dari : http://pur07.wordpress.com/2009/07/05/fisi ologi-imun-dan-mekanisme-pertahanan

12. Zahorec R. Ratio of neutrophil to lymphocyte counts-rapid and simple parameter of systemic inflammation and stress in critically ill. PubMed. 2001; 102(1): 5-14.

13. Hadinegoro SR, Moedjito I, Chairulfatah A. Pedoman diagnosis dan tata laksana infeksi virus dengue pada anak. Edisi ke-1. Jakarta: Badan Penerbit Ikatan Dokter Anak Indonesia; 2014.p.12;13;22;36-7.

14. Dorland WAN. Kamus kedokteran dorland. Ed 31. Jakarta : EGC ;2010. p.572; 1261; 1477.

15. Risniati Y, Tarigan LH, Tjitra E. Leukopenia sebagai prediktor terjadinya sindrom syok dengue pada anak dengan demam berdarah dengue. Media Litbang Kesehatan. 2011; 21: 97-101. 